\title{
Correction to: Sophoridine induces apoptosis and S phase arrest via ROS- dependent JNK and ERK activation in human pancreatic cancer cells
}

Zihang $\mathrm{Xu}^{1 \dagger}$, Fei Zhang ${ }^{2 \dagger}$, Chao Bai ${ }^{3 \dagger}$, Chao Yao ${ }^{1}$, Hairong Zhong ${ }^{1}$, Chunpu Zou ${ }^{1 *}$ and Xiao Chen ${ }^{1 *}$

\section{Correction to: J Exp Clin Cancer Res 36, 124 (2017)}

https://doi.org/10.1186/s13046-017-0590-5

Following publication of the article [1], the authors identified errors in Fig. 7; specifically panels in Fig. $7 \mathrm{~g}$ (H\&E staining of liver and kidney from the control and Sophoridine group). The corrected figure can be found below. The corrections do not change the results or the conclusions of this paper.

The original article has been updated.

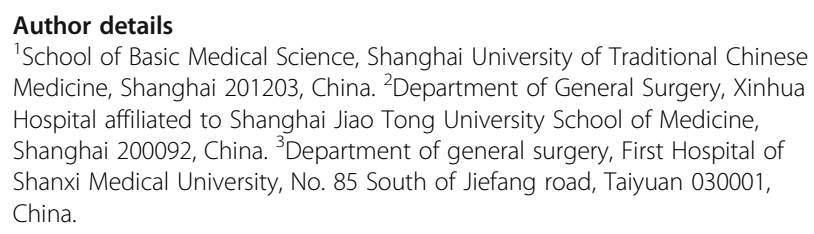

Published online: 26 November 2020

\section{Reference}

1. $\quad \mathrm{Xu} Z$, et al. Sophoridine induces apoptosis and $\mathrm{S}$ phase arrest via ROSdependent JNK and ERK activation in human pancreatic cancer cells. J Exp Clin Cancer Res. 2017;36:124. https://doi.org/10.1186/s13046-017-0590-5.

\footnotetext{
The original article can be found online at https://doi.org/10.1186/s13046017-0590-5.

*Correspondence: chunpuzou@shutcm.edu.cn; chenxiao2121@126.com

${ }^{\dagger}$ Zihang Xu, Fei Zhang and Chao Bai contributed equally to this work.

'School of Basic Medical Science, Shanghai University of Traditional Chinese Medicine, Shanghai 201203, China

Full list of author information is available at the end of the article
}

(c) The Author(s). 2020 Open Access This article is licensed under a Creative Commons Attribution 4.0 International License, which permits use, sharing, adaptation, distribution and reproduction in any medium or format, as long as you give appropriate credit to the original author(s) and the source, provide a link to the Creative Commons licence, and indicate if changes were made. The images or other third party material in this article are included in the article's Creative Commons licence, unless indicated otherwise in a credit line to the material. If material is not included in the article's Creative Commons licence and your intended use is not permitted by statutory regulation or exceeds the permitted use, you will need to obtain permission directly from the copyright holder. To view a copy of this licence, visit http://creativecommons.org/licenses/by/4.0/ The Creative Commons Public Domain Dedication waiver (http://creativecommons.org/publicdomain/zero/1.0/) applies to the data made available in this article, unless otherwise stated in a credit line to the data. 


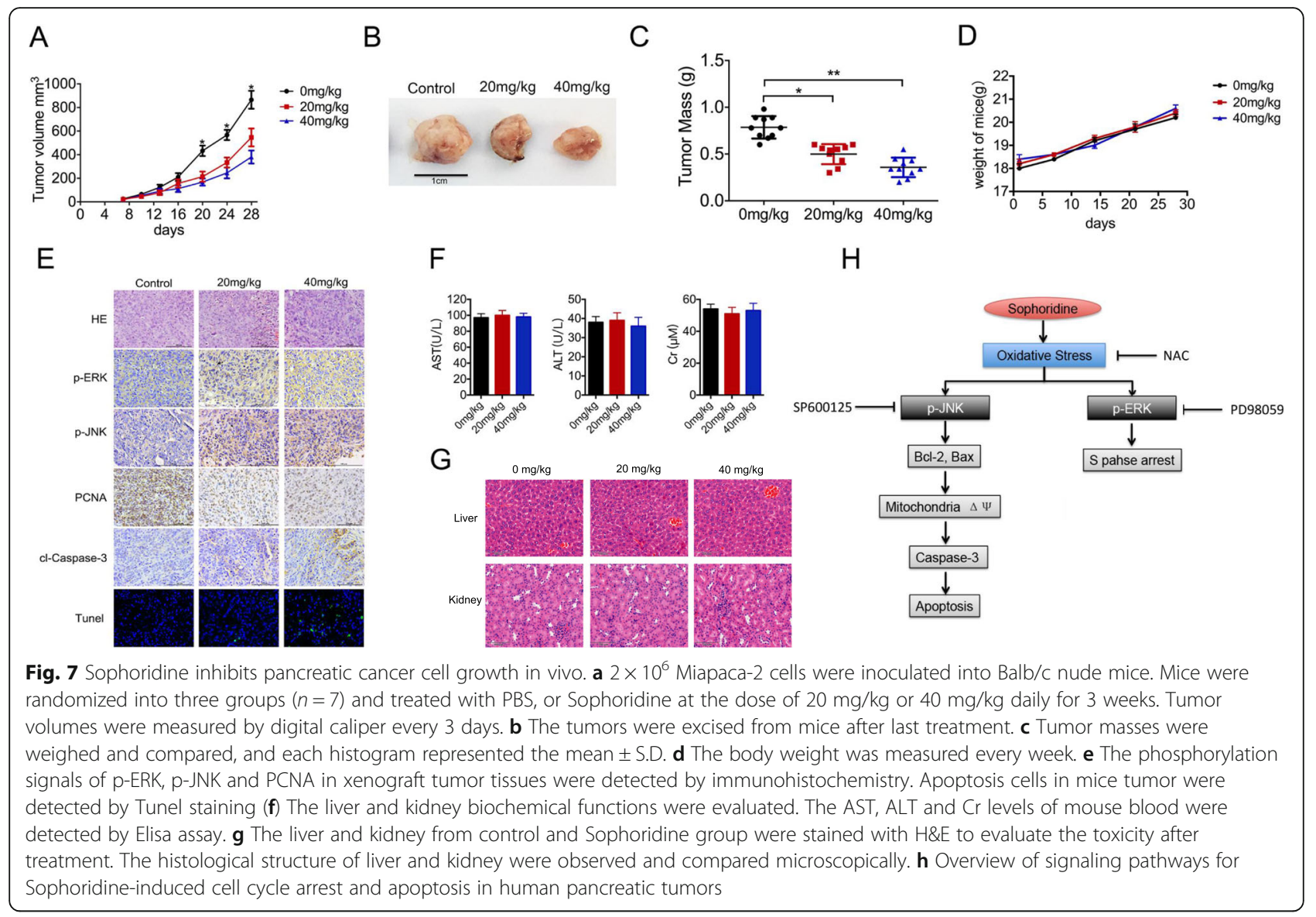

